\title{
INHIBISI XANTIN OKSIDASE OLEH EKSTRAK DAUN SALAM (Syzygium polyanthum)
}

\author{
Nur Candra Eka Setiawan, Ana Nurjanah \\ Program Studi D-III Farmasi \\ Akademi Farmasi Putra Indonesia Malang \\ E-mail : nurcandra@akfarpim.ac.id
}

\begin{abstract}
Abstrak
Xantin oksidase adalah enzim yang berperan dalam pembentukan asam urat. Xantin oksidase mengkatalisis hipoxantin menjadi xantin kemudian menjadi asam urat. Tanaman daun salam mampu menurunkan kadar asam urat darah karena mengandung metabolit sekunder seperti flavonoid, alkaloid, tanin dan minyak atsiri. Penelitian ini bertujuan untuk mengetahui daya hambat enzim xantin oleh ekstrak daun salam. Penelitian ini menggunakan metode penelitian ekperimental yang dilakukan di Laboratorium Farmakognosi Akademi Farmasi Putra Indonesia Malang. Tahap penelitian meliputi, ekstraksi, isolasi enzim, uji aktivitas enzim dan uji daya inhibisi enzim. Pengujian aktivitas penghambatan xantin oksidase menggunakan metode spektrofotometi pada $\lambda 290 \mathrm{~nm}$. Hasil penelitian menunjukkan bahwa pada varian konsentrasi 5 ppm, 10 ppm, 20 ppm, 50 ppm dan 100 ppm dihasilkan berturut-turut $\%$ inhibisinya yaitu $100 \%, 0 \%, 100 \%, 100 \%$, dan $0 \%$. Allopurinol digunakan sebagai kontrol positif dengan varian konsentrasi yang sama dihasilkan $\%$ inhibisi $100 \%, 0 \%, 0 \%, 0 \%$, dan 100\%. Berdasarkan hasil penelitian, ekstrak daun salam dengan konsentrasi 5 ppm memiliki \% inhibisi sebesar 100\% setara dengan allopurinol 5 ppm. Sedangkan pada konsentrasi 100 ppm ekstrak daun salam tidak menunjukkan aktivitas penghambatan yaitu $0 \%$. Hasil penelitian menunjukkan bahwa daun salam memiliki aktivitas penghambatan enzim xantin oksidase sehingga diharapkan dapat dimanfaatkan sebagai obat alternatif dalam menurunkan asam urat.
\end{abstract}

Kata-kata kunci: Daun salam, Inhibisi, Xantin oksidase

\begin{abstract}
Xhantine oxidase is an enzyme that plays a role in the formation of uric acid. Xanthine oxidase catalyzes hypoxanthine into xantin and then becomes uric acid. Bay leaf plants can lower blood uric acid level because it contains secondary metabolites such as flavonoid, tannin, and essential oil. This reseach aimed are to find out xhantine oxidase inhibition by bay leaf extract. This reseach use experimental research method which done in pharmacognosi of pharmacy of Putra Indonesia Malang. The reseach include extraction, isolation of xanthine oxidase enzyme, enzyme activity test and enzyme inhibition test. Testing of enzyme activity of xanthine oxidase inhibition using spectrophotometric at $\lambda 290 \mathrm{~nm}$. The result showes that in variant concentrations of $5 \mathrm{ppm}, 10 \mathrm{ppm}, 20 \mathrm{ppm}, 50 \mathrm{ppm}$ dan $100 \mathrm{ppm}$ were produced inhibitions is \%, 0\%, 100\%,100\%,0\%. Allopurinol is used as a positive control with the same concentration, the \% inhibition is 100\%, 0\%, 0\%, 0\%, dan 100\%. Based on the result, the bay leaf extract with a concentration of $5 \mathrm{ppm}$ has $100 \%$ inhibition equivalent to allopurinol 5 ppm. Concentration 100 ppm of bay leaf extract not show inhibitory activity. The result showed that bay leaf extract has actiivity inhibition of xanthine oxidase, expected to be used as an alternative medicine for uric acid.
\end{abstract}

Keywords: Bay leaf, inhibition, Xanthine Oxidase

\section{PENDAHULUAN}

Asam urat terbentuk dari hasil akhir katabolisme purin yang dibantu oleh enzim xantin oksidase (Darusalam dkk, 2016). Pada proses pembentukan asam urat, xantin oksidase memiliki peranan penting yaitu mengkatalisis berturut-turut hipoxantin menjadi xantin kemudian menjadi asam urat (Haidari et al, 2009). Jika kadar purin dalam tubuh meningkat akan memicu kerja enzim xantin dalam membentuk asam urat. Sehingga asam urat dalam tubuh akan meningkat dan terjadi hiperurisemia (Azmi, 2010).

Penderita asam urat dalam terapinya sering menggunakan obat allopurinol sebagai obat penurun kadar asam urat (Astuti, dan Tjahjono, 2018). Allopurinol bekerja dengan cara menghambat kerja enzim xantin oksidase dalam 
membentuk asam urat karena memiliki struktur mirip xantin (Muhtadi dkk, 2015). Xantin merupakan substrat dari Xantin oksidase. Allopurinol memiliki efek samping seperti mual, diare, dan kulit kemerahan disertai gatal, nyeri kepala, serta kerusakan hati dan ginjal (Cendrianti dkk, 2014). Oleh karena itu, perlu adanya alternatif pengobatan yang aman sebagai inhibitor alami xantin oksidase. WHO merekomendasikan penggunaan obat herbal dalam pengobatan penyakit. Penggunaan obat herbal secara umum dinilai lebih aman dibandingkan obat modern.

Salah satu tanaman yang secara empiris dipercaya dapat menurunkan kadar asam urat adalah daun salam (Syzygium polyanthum) (Djohari dan Rovi, 2015). Dikalangan masyarakat Indonesia daun salam sudah tidak asing lagi biasanya digunakan untuk penyedap masakan karena aromanya. Selain digunakan untuk penyedap masakan juga dapat digunakan sebagai alternatif obat tradisional. Daun salam dapat digunakan untuk pengobatan kolesterol, diabetes melitus, hipertensi, gastritis dan diare (Djohari dan Rovi, 2015). Daun salam mengandung bahan kimia berupa minyak asiri, tanin, dan flavonoida (Djohari dan Rovi, 2015). Beberapa senyawa antioksidan memiliki potensi sebagai inhibitor xantin oksidase. Flavonoid juga memiliki aktivitas menghambat xantin oksidase karena posisi gugus hidroksilnya lebih mudah menangkap elektron dari sisi aktif xantin oksidase (Yanti dkk,2016).

Berdasarkan uraian tersebut maka diperlukan metode yang tepat yaitu dengan melakukan maserasi dengan menggunakan pelarut etanol $70 \%$ dengan lama perendaman 3 hari. Metode ini memiliki beberapa keuntungan yaitu mampu mengurangi rusaknya senyawa yang terkandung akibat pemanasan (Setiawan dan Febrianti, 2017). Ekstrak etanol yang didapatkan diuji daya inhibisinya terhadap enzim xantin oksidase. Enzim xantin oksidase yang diperoleh dari isolasi susu sapi segar. Kemudian digunakan metode spektrofotometri untuk mengetahui nilai absorbansi. Absorbansi yang diukur merupakan jumlah produksi asam urat. Sehingga didapatkan $\%$ inhibisi dari ekstrak daun salam dengan allopurinol.

\section{METODE}

Penelitian inhibisi xantin oksidase oleh ekstrak daun salam (Syzygium polyanthum) ini termasuk penelitian ekperimental.

Adapun tahap penelitian sebagai berikut.

1.Determinasi tanaman salam dilakukan di Materia Medika Batu, Jawa Timur

2.Ekstraksi metode maserasi dengan menggunakan pelarut etanol 70\%. Perbandingan 1:5 b/v selama 3 hari dan remaserasi 3 kali selanjutnya dipekatkan menggunakan vacum evaporator dan waterbath.

3.Skrining fitokimia ekstrak etanol daun salam

4.Isolasi enzim xantin oksidase dari $250 \mathrm{~mL}$ susu sapi segar. Dipanaskan susu sapi segar sebanyak $250 \mathrm{~mL}$ hingga suhu $30^{\circ} \mathrm{C}$. Ditambahkan 81,68 $\mathrm{g} \mathrm{NaCl}$ dan disetrifugasi dengan kecepatan 4000 rpm selama 30 menit. Supernatan yang diperoleh difraksinasi menggunakan amonium sulfat $40 \%$ dan disimpan pada suhu $4^{\circ} \mathrm{C}$. Disentrifugasi dengan kecepatan $4000 \mathrm{rpm}$ selama 75 menit menggunakan sentrifuge. Supernatan dan residu yang diperoleh digunakan sebagai sampel enzim xantin oksidase. Dilarutkan fraksi residu menggunakan buffer fosfat 0,05 M pH 7,5 hingga $250 \mathrm{~mL}$.

5.Penentuan Aktivitas Xanthine Oksidase (Cendrianti, dkk, 2014). Diambil 200 $\mu$ l substrat xanthine oxidase dengan konsentrasi $100 \mu \mathrm{g} / \mathrm{ml}$. Diambil $100 \mu$ xanthine oksidase dicampurkan substrat xantine dengan xantin oksidase dan ditambahkan buffer fosfat $\mathrm{pH}$ 7,5 sebanyak $724 \mu 1$. Aktivitas xanthine oksidase diukur dengan spektrofotometri pada $\lambda 290 \mathrm{~nm}$. Kecepatan pembentukan asam urat diamati dari menit ke-0 sampai menit ke-40. Data yang diperoleh berupa absorbansi.

6.Metode Uji Inhibisi Ekstrak Daun Salam (Cendrianti, dkk, 2014). Diambil 200 $\mu$ l substrat xanthine dengan konsentrasi $100 \mu \mathrm{g} / \mathrm{ml}$. Diambil $100 \mu 1$ xanthine oksidase dengan konsentrasi 50mU/ml. Diambil 200 $\mu$ l larutan uji (ekstrak). Dicampurkan substrat xantine, xantin oksidase dan larutan uji. Ditambahkan buffer fosfat $\mathrm{pH}$ 7,5 sebanyak $724 \mu 1$. Aktivitas xanthine oksidase diukur dengan spektrofotometri pada $\lambda 290 \mathrm{~nm}$. Kecepatan pembentukan asam urat diamati dari menit ke-0 sampai menit ke-40. Data yang 
diperoleh berupa absorbansi. Dengan cara yang sama diujikan pada allopurinol.

\section{HASIL DAN PEMBAHASAN}

Hasil ekstraksi didapatkan ekstrak etanol daun salam berwarna hijau tua hampir beerwarna hitam. Hasil perhitungan rendemen ekstraksi daun salam ditunjukkan pada Tabel 1.

Ekstrak etanol daun salam diuji fitokimia untuk mengidentifikasi senyawa yang terdapat dalam ekstrak. Uji fitokimia yang dilakukan meliputi uji flavonoid, alkaloid, tanin, fenol, saponin, steroid dan triterpenoid. Tabel 2 menunjukkan hasil uji fitokimia dalam ekstrak etanol daun salam adalah flavonoid, saponin, tanin, fenol.

Hasil isolasi enzim xantin oksidase diperoleh residu dan supernatan. Keduanya diuji aktivitasnya dengan cara mengukur absorbansi pembentukan asam urat pada panjang gelombang maksimal $290 \mathrm{~nm}$. Absorbansi yang diukur merupakan jumlah produksi asam urat.

Xantin oksidase akan mengendap pada amonium sulfat $40 \%$ (Ernawati, 2014). Aktivitas enzim tertinggi ditunjukkan pada fraksi residu sebesar 1.10-5 U/mL. Adanya aktivitas enzim pada fraksi supernatan disebabkan karena masih ada enzim yang tidak terendapkan pada amonium sulfat $40 \%$. Aktivitas xantin oksidase dapat dilihat pada Tabel 3 dan kurva uji aktivitas pada supernatan dan residu dapat dilihat pada Gambar 1 dan 2.

Berdasarkan Tabel 4. pada uji inhibisi xantin oksidase menunjukkan ekstrak daun salam dengan konsentrasi 5 ppm dan $\%$ inhibisinya setara dengan allopurinol $5 \mathrm{ppm}$ yaitu $100 \%$. Sedangkan pada konsentrasi 10 ppm \% inhibisi pada ekstrak dan allopurinol mengalami penurunan yaitu $0 \%$ artinya pada konsentrasi tersebut tidak dapat menghambat kerja xantin oksidase. Selanjutnya pada konsentrasi ekstrak 20 ppm dan 50 ppm \% inhibisinya mengalami kenaikan yaitu $100 \%$. Sebaliknya pada konsentrasi yang sama pada allopurinol tidak dapat menghambat xantin oksidase yaitu sebesar 0\%. Pada konsentrasi 100 ppm pada ekstrak dihasilkan \% inhibisi sebesar 0\% sedangkan pada allopurinol sebesar 100\%. Daya Inhibisi ekstrak daun salam dapat dilihat pada Tabel 4.

Hasil uji menunjukkan tidak semua varian konsentrasi ekstrak daun salam dan kontrol positif allopurinol memiliki daya inhibisi xantin oksidase. Hal ini dapat dipengaruhi oleh beberapa faktor diantaranya konsentrasi enzim, konsentrasi substrat, adanya senyawa inhibitor dan aktivator, $\mathrm{pH}$, dan suhu. Namun, dilihat dari konsentrasi terendah keduanya dapat menghambat sebesar $100 \%$. Sedangkan dilihat dari konsentrasi tertinggi keduanya memiliki perbedaan yaitu pada ekstrak tidak dapat menghambat dan sebaliknya pada allopurinol.

Tabel 1. Rendemen Ekstrak Daun Salam

\begin{tabular}{cccc}
\hline Jenis Pelarut & Massa Sampel $(\mathrm{g})$ & Massa Ekstrak $(\mathrm{g})$ & Rendemen $(\%)$ \\
\hline Etanol 70\% & 250 & 33,52 & 13,41 \\
\hline
\end{tabular}

Tabel 2. Hasil Uji Fitokimia Ekstrak Daun Salam

\begin{tabular}{ll}
\hline Golongan Senyawa & Hasil Uji \\
\hline Flavonoid & + \\
Alkaloid & - \\
$\quad$ Mayer & - \\
$\quad$ Wagner & - \\
Tanin & + \\
Saponin & + \\
Fenol & + \\
\hline
\end{tabular}


Tabel 3.Aktivitas Xantin Oksidase pada fraksi amonium sulfat $40 \%$

\begin{tabular}{ccccc}
\hline Fraksi & $\begin{array}{c}\text { Waktu } \\
\text { (menit) }\end{array}$ & Absorbansi & $\begin{array}{c}\text { Konsentrasi } \\
\text { Asam Urat } \\
(\mathrm{mM})\end{array}$ & $\begin{array}{c}\text { Aktivitas XO } \\
(\mathrm{U} / \mathrm{mL})\end{array}$ \\
\hline Supernatan & 0 & 0,297 & 0,024 & \\
& 10 & 0,295 & 0,024 & 0 \\
\hline \multirow{2}{*}{ Residu } & 20 & 0,299 & 0,024 & 0,00005 \\
& 0 & 0,635 & 0,052 & \\
\hline
\end{tabular}

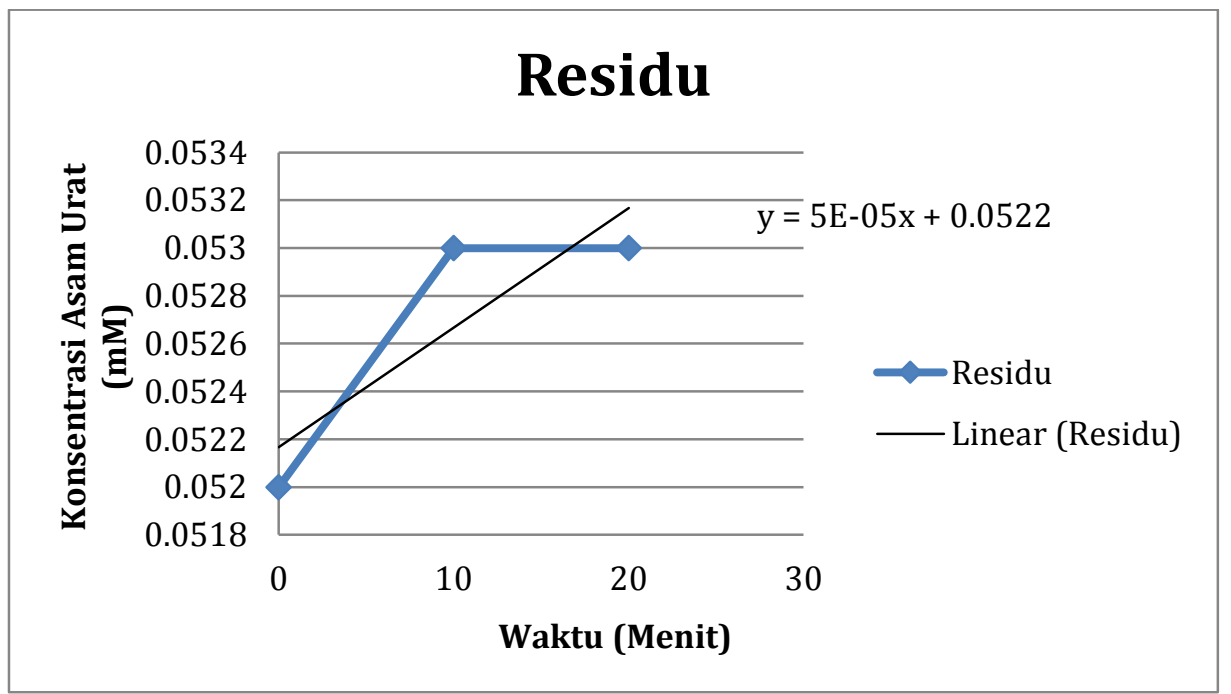

Gambar 1. Kurva Aktivitas Xantin Oksidase Pada Residu

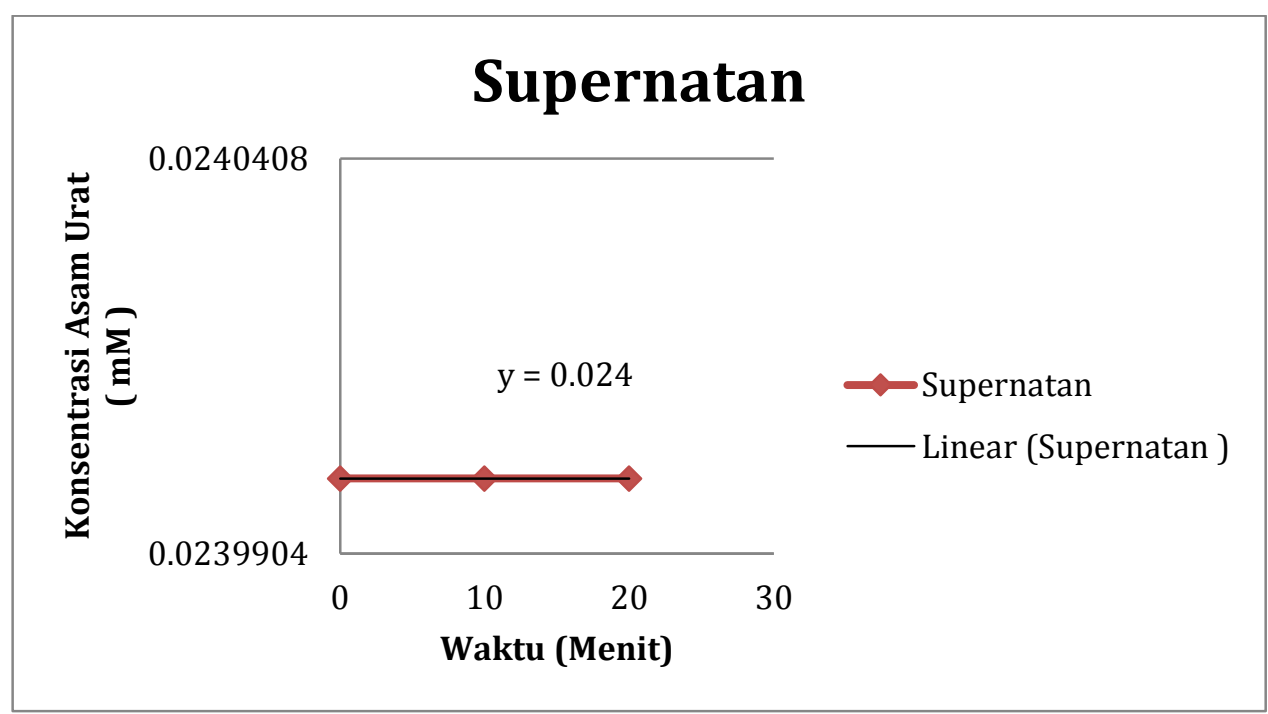

Gambar 2. Kurva Aktivitas Xantin Oksidase Pada Supernatan 
Tabel 4. Daya Inhibisi Allopurinol dan Ekstrak Daun Salam

\begin{tabular}{|c|c|c|c|c|c|}
\hline Fraksi & $\begin{array}{l}\text { Waktu } \\
\text { (menit) }\end{array}$ & Absorbansi & $\begin{array}{c}\text { Konsentrasi } \\
\text { Asam Urat } \\
(\mathrm{mM})\end{array}$ & $\begin{array}{c}\text { Aktivitas } \\
\mathrm{XO} \\
(\mathrm{U} / \mathrm{mL})\end{array}$ & $\begin{array}{c}\text { Daya } \\
\text { Inhibisi } \\
(\%)\end{array}$ \\
\hline \multirow{3}{*}{$\begin{array}{c}\text { Tanpa } \\
\text { inhibitor }\end{array}$} & 0 & 0,325 & 0,026 & \multirow{3}{*}{0,00005} & \multirow{3}{*}{$0 \%$} \\
\hline & 10 & 0,327 & 0,026 & & \\
\hline & 20 & 0,33 & 0,027 & & \\
\hline \multirow{3}{*}{ Ekstrak 5 ppm } & 0 & 0,387 & 0,031 & \multirow{3}{*}{0} & \multirow{3}{*}{$100 \%$} \\
\hline & 10 & 0,389 & 0,031 & & \\
\hline & 20 & 0,39 & 0,031 & & \\
\hline \multirow{3}{*}{$\begin{array}{c}\text { Ekstrak } 10 \\
\text { ppm }\end{array}$} & 0 & 0,372 & 0,03 & \multirow{3}{*}{0,00005} & \multirow{3}{*}{$0 \%$} \\
\hline & 10 & 0,373 & 0,03 & & \\
\hline & 20 & 0,377 & 0,031 & & \\
\hline \multirow{3}{*}{$\begin{array}{c}\text { Ekstrak } 20 \\
\text { ppm }\end{array}$} & 0 & 0,331 & 0,027 & \multirow{3}{*}{0} & \multirow{3}{*}{$100 \%$} \\
\hline & 10 & 0,334 & 0,027 & & \\
\hline & 20 & 0,335 & 0,027 & & \\
\hline \multirow{3}{*}{$\begin{array}{c}\text { Ekstrak } 50 \\
\text { ppm }\end{array}$} & 0 & 0,437 & 0,036 & \multirow{3}{*}{0} & \multirow{3}{*}{$100 \%$} \\
\hline & 10 & 0,438 & 0,036 & & \\
\hline & 20 & 0,442 & 0,036 & & \\
\hline \multirow{3}{*}{$\begin{array}{c}\text { Ekstrak } 100 \\
\text { ppm }\end{array}$} & 0 & 0,486 & 0,04 & \multirow{3}{*}{0,00005} & \multirow{3}{*}{$0 \%$} \\
\hline & 10 & 0,493 & 0,04 & & \\
\hline & 20 & 0,503 & 0,041 & & \\
\hline \multirow{3}{*}{$\begin{array}{l}\text { Allopurinol } 5 \\
\text { ppm }\end{array}$} & 0 & 0,367 & 0,03 & \multirow{3}{*}{0} & \multirow{3}{*}{$100 \%$} \\
\hline & 10 & 0,376 & 0,03 & & \\
\hline & 20 & 0,375 & 0,03 & & \\
\hline $\begin{array}{l}\text { Allopurinol } \\
10 \mathrm{ppm}\end{array}$ & 0 & 0,363 & 0,029 & 0,00005 & $0 \%$ \\
\hline
\end{tabular}




\begin{tabular}{|c|c|c|c|c|c|}
\hline & 10 & 0,368 & 0,03 & & \\
\hline & 20 & 0,368 & 0,03 & & \\
\hline \multirow{3}{*}{$\begin{array}{l}\text { Allopurinol } \\
20 \mathrm{ppm}\end{array}$} & 0 & 0,389 & 0,031 & \multirow{3}{*}{0,00005} & \multirow{3}{*}{$0 \%$} \\
\hline & 10 & 0,391 & 0,032 & & \\
\hline & 20 & 0,394 & 0,032 & & \\
\hline \multirow{3}{*}{$\begin{array}{l}\text { Allopurinol } \\
50 \mathrm{ppm}\end{array}$} & 0 & 0,285 & 0,023 & \multirow{3}{*}{0,00005} & \multirow{3}{*}{$0 \%$} \\
\hline & 10 & 0,289 & 0,024 & & \\
\hline & 20 & 0,29 & 0,024 & & \\
\hline \multirow{3}{*}{$\begin{array}{l}\text { Allopurinol } \\
100 \text { ppm }\end{array}$} & 0 & 0,327 & 0,027 & \multirow{3}{*}{0} & \multirow{3}{*}{$100 \%$} \\
\hline & 10 & 0,33 & 0,027 & & \\
\hline & 20 & 0,331 & 0,027 & & \\
\hline
\end{tabular}

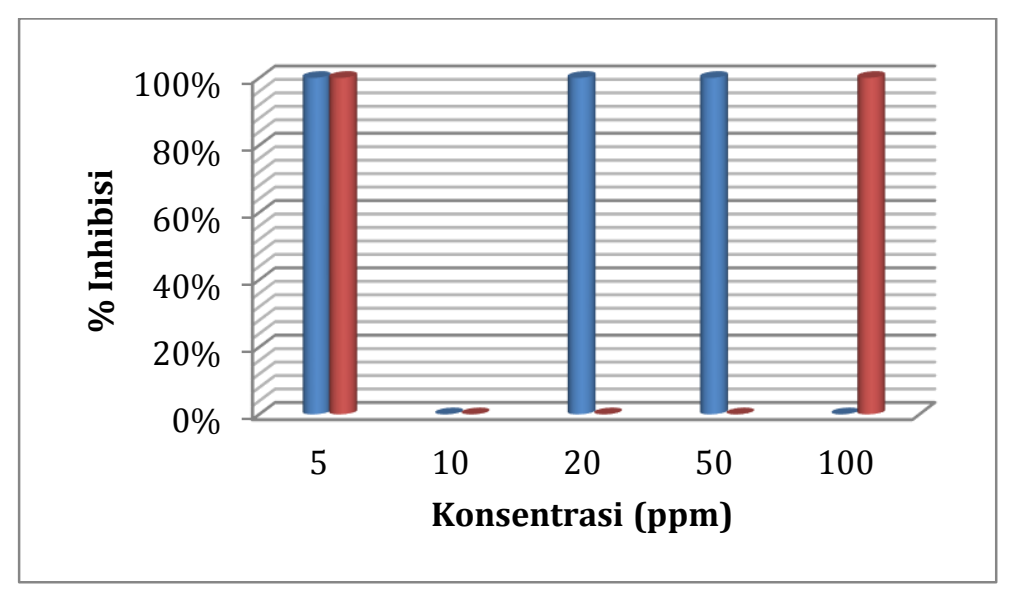

Gambar 3. Daya Inhibisi Pada Ekstrak \& Allopurinol

\section{KESIMPULAN}

Ekstrak daun salam pada konsentrasi 5 ppm mampu menginhibisi sebesar $100 \%$ yang setara dengan allopurinol dengan konsentrasi yang sama. Sedangkan pada konsentrasi $100 \mathrm{ppm}$ ekstrak tidak dapat menghambat dengan \% inhibisi $0 \%$ sebaliknya pada allopurinol daya inhibinya $100 \%$.

\section{DAFTAR RUJUKAN}

Astuti, Setyo T.W dan Tjahjono ,Hendro Djoko. 2018.

Faktor-faktor Yang Mempengaruhi Kadar Asam Urat (Gout) Pada Laki-laki Dewasa Di 
RT 04 RW 03 Simomulyo Baru Surabaya. Ejournal stikeswilliambooth : Surabaya

Azmi, Ulul. 2010. Efek Ekstrak Etanol Daging Buah Mahkota Dewa Terhadap Penurunan Kadar Asam Urat Pada Mencit Putih Jantan Yang Diinduksi Potassium Oxonate. Skripsi. Universitas Muhammadiyah: Surakarta.

Cendrianti, F., Muslichah, S., dan Ulfa, E.U. 2014. Uji Aktivitas Antihiperurisemia Ekstrak nHeksana, Etil Asetat, danEtanol 70\% Daun Tempuyung (Sonchus arvensis L.) pada Mencit Jantan Hiperurisemia. e-Jurnal Pustaka Kesehatan

Darussalam, Miftafu dan Rukmi, Dwi Kartika. 2016. Peran Air Rebusan Daun Salam (Syzygium polyanthum) Dalam Menurunkan Kadar Asam Urat. Jurnal Ilmu Kesehatan Vol.5(2).

Djohari, Meiriza, dan Rovi, Paramitha. 2015. Efektivitas Rebusan Daun Salam (Syzygium polyanthum)Terhadap Penurunan Kadar Asam Urat Dalam Darah Mencit Putih Jantan. Jurnal Pharmacy Vol.12(2).

Yanti, RA, Rahayu, TS, dan Syachfitri, DR. 2016. Uji Aktivitas Penghambatan Xantin Oksidase Secara In vitro Oleh Isolat 6,4-Dihiroksi-4Metoksibenzofeno2-O- $\beta$-D Glukopiranosida Yang Diisolasi Dari Mahkota Dewa (Phaleria macrocarpa).Pharm Sci Res Vol. 3 (1): 2407 2354.

Ernawati, Hari Susanti. 2014. Penghambatan Aktivitas xanthine Oksidase Oleh Ekstrak Etanol Sarang Semut Secara In Vitro. Jurnal Pharmaciana Vol. 4 (1): 15-22.

Haidari, F.; Shahi, M. Mohammad; Keshavarz, S. A.; Rashidi, M. R. 2009. Inhibitory Effects of Tart Cherry (Prunus cerasus) Juice on Xanthine Oxidoreductase Activity and its Hypouricemic and Antioxidant Effects on Rats. Malaysian Journal of Nutrition . Vol. 15 Issue 1, p53-64
Muhtadi, Nurcahyanti Wahyuningtyas, EM Sutrisna, Andi Suhendi, dan Heny Frastyowati. 2015. Uji Penghambatan Xanthine Oksidase Oleh Ekstrak Daun Tempuyung (Sonchus arvensis) Pada Mencit Hiperurisemia. University Research Colloquium.

Setiawan, N.C.E., Febriyanti, A., 2017. Aktivitas Antioksidan Ekstrak Etanol dan Fraksi-Fraksi Umbi Eleutherine palmifolia (L.) Merr dengan Metode DPPH. JCPS J. Curr. Pharm. Sci. 1, 1. 